Portland State University

PDXScholar

Environmental Science and Management

Faculty Publications and Presentations

2008

\title{
Engaging Recreational Fishers in Management and Conservation: Global Case Studies
}

\author{
Elise F. Granek \\ Portland State University, graneke@pdx.edu \\ Elizabeth M.P. Madin \\ M. A. Brown \\ U.S. Bureau of Land Management \\ Will F. Figueira \\ University of Technology, Sydney \\ Darren S. Cameron \\ Great Barrier Reef Marine Park Authority
}

See next page for additional authors

Follow this and additional works at: https://pdxscholar.library.pdx.edu/esm_fac

Part of the Aquaculture and Fisheries Commons, Environmental Sciences Commons, and the Zoology Commons

Let us know how access to this document benefits you.

\section{Citation Details}

GRANEK, E. F., MADIN, E. P., BROWN, M. A., FIGUEIRA, W. W., CAMERON, D. S., HOGAN, Z. Z., \& ... ARLINGHAUS, R. R. (2008). Engaging Recreational Fishers in Management and Conservation: Global Case Studies. Conservation Biology, 22(5), 1125-1134.

This Article is brought to you for free and open access. It has been accepted for inclusion in Environmental Science and Management Faculty Publications and Presentations by an authorized administrator of PDXScholar. Please contact us if we can make this document more accessible: pdxscholar@pdx.edu. 


\section{Authors}

Elise F. Granek, Elizabeth M.P. Madin, M. A. Brown, Will F. Figueira, Darren S. Cameron, Zeb Hogan, Gerry Kristianson, Pierre de Villiers, Jack E. Williams, John R. Post, S. Zahn, and R. Arlinghaus 


\title{
Engaging Recreational Fishers in Management and Conservation: Global Case Studies
}

\author{
E. F. GRANEK, ${ }^{*}$ E. M. P. MADIN,$\dagger^{* * * *}$ M. A. BROWN,$\ddagger^{* * * *}$ W. FIGUEIRA,$\oint^{* * * *}$ D. S. CAMERON, ${ }^{* *}$

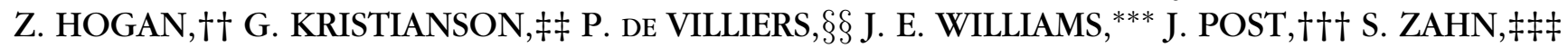
AND R. ARLINGHAUS $\S \S \S$

\author{
${ }^{*}$ Environmental Science and Management, Portland State University, P.O. Box 751, Portland, OR 92707, U.S.A., email \\ graneke@pdx.edu \\ †Department of Ecology, Evolution and Marine Biology, University of California, Santa Barbara, CA 93106, U.S.A. \\ ¥U.S. Bureau of Land Management, P.O. Box 2965, Portland, OR 97204, U.S.A. \\ $\S$ Department of Environmental Sciences, University of Technology, Sydney, P.O. Box 123 Broadway, NSW 2007, Australia \\ ${ }^{* *}$ Great Barrier Reef Marine Park Authority, P.O. Box 1379, Townsville, QLD 4810, Australia \\ t†Department of Natural Resources and Environmental Science, University of Nevada-Reno, 1000 Valley Road, M.S. 186, Reno, \\ NV 89512, U.S.A. \\ $\ddagger \ddagger$ Sport Fishing Institute, 67 McKenzie Crescent, Sidney, BC V8L 5Y7, Canada \\ $\S \S$ C.A.P.E. Estuaries Programme, CapeNature, Private Bag 5014, Stellenbosch 7599, South Africa \\ ***Trout Unlimited, 329 Crater Lake Avenue, Medford, OR 97504, U.S.A. \\ t††Department of Biological Sciences, University of Calgary, 2500 University Drive, Calgary, AB T2N 1N4, Canada

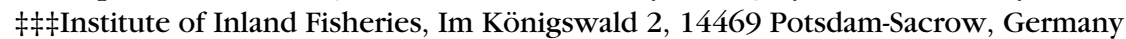 \\ $\S \S \S$ Leibniz-Institute of Freshwater Ecology and Inland Fisheries, Department of Biology and Ecology of Fishes, Müggelseedamm 310, \\ 12587 Berlin, Germany, and Humboldt-University of Berlin, Institute of Animal Sciences, Inland Fisheries Management Lab, \\ Philippstrasse 13, Haus 7, 10115 Berlin, Germany
}

\begin{abstract}
Globally, the number of recreational fishers is sizeable and increasing in many countries. Associated with this trend is the potential for negative impacts on fish stocks through exploitation or management measures such as stocking and introduction of non-native fishes. Nevertheless, recreational fishers can be instrumental in successful fisheries conservation through active involvement in, or initiation of, conservation projects to reduce both direct and external stressors contributing to fishery declines. Understanding fishers' concerns for sustained access to the resource and developing methods for their meaningful participation can have positive impacts on conservation efforts. We examined a suite of case studies that demonstrate successful involvement of recreational fishers in conservation and management activities that span developed and developing countries, temperate and tropical regions, marine and freshwater systems, and open-and closedaccess fisheries. To illustrate potential benefits and challenges of involving recreational fishers in fisheries management and conservation, we examined the socioeconomic and ecological contexts of each case study. We devised a conceptual framework for the engagement of recreational fishers that targets particular types of involvement (enforcement, advocacy, conservation, management design [type and location], research, and monitoring) on the basis of degree of stakeholder stewardship, scale of the fishery, and source of impacts (internal or external). These activities can be enbanced by incorporating local knowledge and traditions, taking advantage of leadership and regional networks, and creating collaborations among various stakeholder groups, scientists, and agencies to maximize the probability of recreational fisher involvement and project success.
\end{abstract}

Keywords: anglers, Atlantic salmon, cutthroat trout, Great Barrier Reef, marine protected areas, recreational fishing, rockfish, stakeholders, taimen, westslope cutthroat trout, yellowfish

\footnotetext{
****Autbors contributed equally

Paper submitted July 18, 2007; revised manuscript accepted January 14, 2008.

Correction added after publication 15 July 2008; Autborship was amended for accuracy.
} 
Involucrando a Pescadores Recreativos en el Manejo y la Conservación: Estudios de Caso Globales

Resumen: Globalmente, el número de pescadores recreativos es considerable y está incrementando en muchos países. Esta tendencia se asocia con el potencial de impactos negativos sobre la disponibilidad de peces mediante la explotación o medidas de manejo como el aprovisionamiento e introducción de peces no nativos. Sin embargo, los pescadores recreativos pueden jugar un papel decisivo en el éxito de la conservación de pesquerías mediante su participación activa en, o en el inicio de, proyectos de conservación para reducir los factores estresantes, tanto directos como externos, que contribuyen a la declinación de las pesquerías. El entendimiento de las preocupaciones de los pescadores por el acceso sustentable al recurso y por el desarrollo de métodos para una participación significativa puede tener impactos positivos sobre los esfuerzos de conservación. Examinamos un conjunto de estudios de caso que demuestran una participación exitosa de pescadores recreativos en actividades de manejo y conservación en países desarrollados y en desarrollo, regiones templadas y tropicales, sistemas marinos y dulceacuícolas y en pesquerías de acceso abierto y cerrado. Para ilustrar los beneficios y retos potenciales de involucrar a pescadores recreativos en el manejo y la conservación de pesquerías, examinamos el contexto socioeconómico y ecológico de cada estudio de caso. Diseñamos un marco conceptual para comprometer a pescadores recreativos que enfoca diferentes tipos de compromiso (coerción, intercesión, conservación, diseño de manejo [tipo y localidades], investigación y monitoreo) con base en el grado de responsabilidad de las partes interesadas, la escala de la pesquería y la fuente de impactos (interna o externa). Estas actividades se pueden mejorar mediante la incorporación del conocimiento y tradiciones locales, el aprovechamiento de las redes regionales de liderazgo y la creación de colaboraciones entre los diferentes grupos de interés, científicos y agencias para maximizar la probabilidad de la participación de pescadores recreativos y el éxito del proyecto.

Palabras Clave: áreas protegidas, gran barrera arrecifal, Oncorbynchus clarki, partes interesadas, pescadores de caña, pesca recreativa, pez roca, Pleurogrammus monopterygius, salmón del Atlántico, trucha

\section{Introduction}

Many of the world's fish populations are in decline. In $200577 \%$ of the global fishery stocks of known status were either fully exploited (52\%), overexploited (17\%), depleted (7\%), or recovering from depletion (1\%; FAO 2006). These declines result from a complex set of processes that are internal and external to the fisheries. For instance, industrialized fishing in marine systems has led to dramatic declines in target stock biomass, alteration of community structure (Pauly et al. 1998; Myers \& Worm 2003), and long-lasting effects on fisheries through habitat destruction (Dayton et al. 1995; Jennings \& Kaiser 1998). Freshwater fishes are also heavily threatened on a global scale (Harrison \& Stiassny 1999). Whereas their overexploitation has played a role, a host of important factors external to the fishery include habitat alteration or destruction (e.g., agriculture and hydropower), water pollution (e.g., eutrophication), flow modification (e.g., for flood control), and introduction and spread of alien species (Arlinghaus et al. 2002; Cambray 2003). Although commercial fishers have taken the brunt of the blame for fisheries stock depletions in the ocean (Cooke \& Cowx 2006), the role recreational fisheries play in fisheries declines is increasingly recognized (Coleman et al. 2004; Cooke \& Cowx 2004, 2006; Lewin et al. 2006). Recreational fisheries, although variable, can be described as noncommercial fishing activities that are not the individual's primary resource to meet essential nutritional needs (Arlinghaus \& Cooke 2008).

\section{Significance of Recreational Fishing}

Recreational fishing is extremely popular worldwide, with average participation rates of around 10\% (Arlinghaus \& Cooke 2008). Harvest by recreational fisheries has been estimated at about $12 \%$ of take worldwide for all fish (Cooke \& Cowx 2004) and 23\% for some overfished U.S. marine fish stocks (Coleman et al. 2004). If recreational fishing has not contributed to stock depletion, it may at least be hindering recovery in some localities (Coleman et al. 2004). In many freshwater systems, especially small lakes and streams, recreational fishing is the only source of fishing mortality and has led to the collapse of at least 4 high-profile Canadian recreational freshwater fisheries (Post et al. 2002).

In addition to the obvious impact of reducing population abundance via harvest mortality, recreational fishing can have other direct and indirect impacts on fished populations and their ecosystems. These impacts include changes in population or community structure due to selective harvest, loss of genetic diversity, catch-andrelease mortality, density- or behaviorally mediated indirect interactions, and disturbance resulting from physical trampling, boat traffic, and noise (Lewin et al. 2006). Among the most significant impacts of recreational fishing are fish stocking and introductions of non-native 
fishes (Arlinghaus et al. 2002). Stocking can threaten indigenous species through competition, predation, hybridization, and introduction of novel pathogens and parasites (Lewin et al. 2006) or via changes in nutrient cycles or food-web structure (Eby et al. 2006). A particularly insidious problem with fish stocking and introduction is that they can mask the exploitation-induced effects of recreational fishing (Post et al. 2002; Lewin et al. 2006).

\section{Recreational Fishers as Conservation Partners}

Despite the negative impacts of recreational fishing, recreational fishers constitute a social group that offers unique potential to positively enhance fish conservation (e.g., Bate 2001; Arlinghaus 2006). Recreational fishers have an inherent interest in the conservation and management of the fisheries resources on which their leisure experience depends (Arlinghaus 2006). Allowing fishers to participate in developing regulations, within the bounds set by available stock information from biologists, could lead to increased management success (Sullivan 2003). Aspects or permutations of active management strategies such as this (e.g., Pereira \& Hansen 2003; Radomski 2003) are particularly relevant under public fishing-rights regimes, where fishers are users of a fishery, but management decisions are made by agencies. A unique opportunity for recreational fishers to be involved in conservation also exists under the private fishing-rights regimes characteristic of central Europe (Arlinghaus et al. 2002), in which management and conservation responsibilities lie with the fisher community through membership in angling clubs and associations that own or hold leases to fishing rights (Arlinghaus 2006).

Here we present a suite of case studies that highlight the potential for recreational anglers to be an important conservation force. Aspects of these cases may be useful for application in other systems because they demonstrate successes and challenges of various strategies of recreational fishers' involvement in achieving conservation objectives. Successful examples include privately governed recreational fisheries (German case study) and open-access fisheries on 4 continents (North America, Africa, Asia, and Australia). Three of the 6 cases focus on salmonids, highlighting simultaneously the worldwide popularity of these fishes for angling and the extreme threats they face. Comparing and contrasting experiences with recreational fishers' involvement in fish conservation in freshwater and marine systems, across a broad geographic spectrum, in developing and developed countries, and under different fisheries management regimes offers key insights into and patterns that demonstrate how such involvement can lead to enhanced conservation effectiveness.

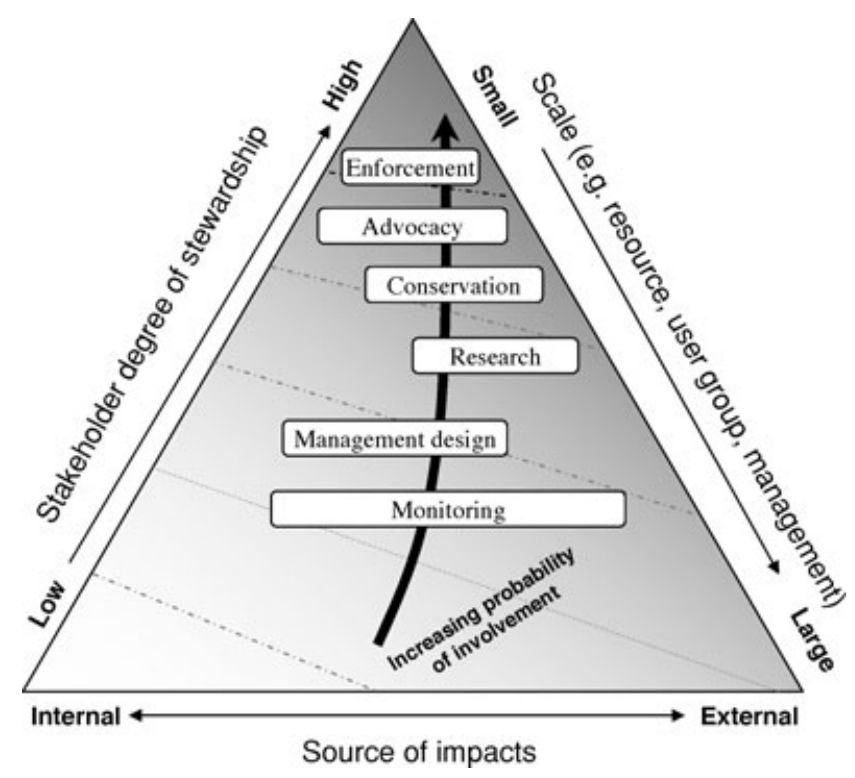

Figure 1. Tri-factor contour plot illustrating the primary factors (on axes) that affect the likelibood of fisher involvement in conservation efforts (darker shades are more likely). The activities highlighted in Table 1 are placed on the surface on the basis of their utility and probability of success given the combination of factors.

\section{Case Studies of Recreational Fisher Participation}

Each case study is framed within a particular sociopolitical and ecological context that provides important insight into understanding the challenges of fisher involvement. The process of involvement and the corresponding outcomes are provided for each conservation and/or management case study. The key lessons learned from involving recreational fishers in the process offer insights to guide future involvement efforts, although each situation is unique and so too must be its prescriptions for success. The case studies are organized by scale from local to regional and highlight the importance of considering scales of key factors in fisher involvement strategies (Fig. 1).

\section{Eurasian Giant Trout in the Eg-Uur Watershed, Mongolia}

The Eurasian giant trout, "taimen" (Hucho taimen), is the world's largest salmonid, attaining sizes of over $100 \mathrm{~kg}$ and $2 \mathrm{~m}$. The taimen, an apex predator, is slow growing, long-lived, and naturally rare making it vulnerable to overexploitation. Recreational fishing is common and threatens taimen, especially where recreational fishers use catch and kill methods (steady extractive fishing = $50 \%$ of the adult population in $2-3$ years and $90 \%$ in 10 years). Mining, overgrazing, deforestation, and pollution are also serious long-term threats to taimen and their habitat. Because of these multiple, often interacting, threats, unaffected populations of taimen are restricted 
to remote watersheds of Russia and Mongolia. The EgUur watershed in northern Mongolia, home to one of the few taimen populations with many large, adult fish, is a prime destination for recreational fishers. Evidence of overharvest has become apparent at the edges of the watershed as the area becomes more accessible and known to fishers (Hogan et al. 2006).

To protect taimen in the Eg-Uur watershed, a local Mongolian NGO, the Taimen Conservation Fund, established a conservation project financed by revenues from recreational fishing. The project provides funds and infrastructure to local managers to prevent a "tragedy of the commons," to increase perceived value of taimen protection, and to facilitate business partnerships between local communities and recreational fishers.

Fishing fees for catch-and-release ecotourism operations are paid to a community watershed council that oversees Eg-Uur River management. Recreational fishers also contribute in-kind support (boat and equipment use, air transportation, fishing expertise, and access to clients' fish for tagging, creel surveys, and spawning fish counts) to the scientific and enforcement teams.

The project's major challenge has been development of a legal instrument to treat wildlife as a locally, rather than federally, managed resource. Without locally based management, communities have little incentive to protect the resource, leading to increased levels of fishing and poaching. Another challenge is developing local funding sources and local scientific and monitoring capacity to ensure long-term sustainability. Partnering with in-country researchers and international conservation organizations to develop local management capacity is one possible avenue for overcoming this challenge.

A major success of the project has been the collaboration between the Taimen Conservation Fund, scientists, and recreational fishers. This cooperation has generated in-kind support and funds and improved understanding of taimen ecology (Hogan et al. 2006). This project has also demonstrated that, at least on a small scale, local residents, scientists, and recreational fishers can work together to study and protect a threatened species.

\section{Diadromous Salmonids in Brandenburg, Germany}

Most European rivers have been altered for flood control, irrigation, navigation, hydropower generation, and agriculture, and these alterations have had devastating impacts on habitat quality. As a result, many fish populations supporting valuable fisheries, including the Atlantic salmon (Salmo salar) and migrating forms of brown trout (S. trutta), were driven to extinction in the German state of Brandenburg in the 19th century (Brämick et al. 1999). In 1997 the Brandenburg Angler Association partnered with fisheries researchers to establish a reintroduction program of diadromous salmonids into the Stepenitz catchment, a tributary of the Elbe River.
A regional project team including anglers, fisheries researchers, and water management professionals convened to attract funding for stocking programs and construction of fish passages to facilitate successful recruitment. The Brandenburg Angler Association was instrumental in contributing funds and workers to conduct restoration measures and monitor restoration success. Further funding was generated from the Brandenburg Fishing Tax, which was financed through fishing licence sales and the European Union.

From 1999 to 2007, 490,000 salmon fry, 340,000 brown trout fry, and 131,500 salmon fingerlings were stocked from genetically similar stocks in Sweden and Denmark (salmon) and Schleswig-Holstein, Germany (migrating brown trout). Moreover, intensive habitat management activities took place to improve the longitudinal connectivity of the Stepenitz system.

To date, approximately $50 \%$ of all migration barriers have been removed in the tributaries of the Stepenitz, and $64 \%$ of potential spawning habitats are now open. Since 2002 returning adult salmon have been observed routinely and the first natural recruitment has occurred, although this species is not yet self-sustaining.

A major lesson of this project was that an initiative by fishers to restore populations of salmon and troutcharismatic species of high fisheries value-was positively viewed by key decision makers, researchers, agencies, and funding bodies regionally and internationally. A positive outcome of the project was enhanced environmental concern and capacity building among fisher communities. The integration of all stakeholders in small project teams allowed for rapid conflict resolution with minimal transaction costs. The major barriers were attracting sustained funding and convincing landowners and water managers to allow rehabilitation activities. The project highlights the important role of local resource users (fishers) as promoters of conservation measures under private fishing-right regimes in Germany (Arlinghaus et al. 2002; Arlinghaus 2006). No restoration measure would have been possible without approval of the Brandenburg Angler Association because this organization holds the lease for fishing rights in the Stepenitz system.

\section{Yellowfish in the Orange Vaal River, South Africa}

In the 1990s, concurrent with sociopolitical development in South Africa, there was a lack of governmental attention to the country's pressing environmental issues. Development of a large recreational fishery of invasive alien species, including trout (Oncorbynchus mykiss), bass (Micropterus dolomieu, M. salmoides), and carp (Cyprinus carpio), was one such management project that had detrimental impacts on local indigenous fish populations (Woodford et al. 2005). A few conservation officials and conservation-minded flyfishers and bank anglers 
deemed necessary a program to restrict the spread of these non-native species, maintain a healthy aquatic habitats, and protect the native species' waterways. Two indigenous indicator species were chosen as targets for a sustainable replacement fishery: largemouth yellowfish (Labeobarbus kimberleyensis) and smallmouth yellowfish (L. aeneus), although the former was listed as near-threatened due to habitat destruction, illegal netting, and overexploitation.

The Orange Vaal River (OVR) is the largest international river system in Southern Africa. In 1996 the Orange Vaal River Yellowfish Conservation and Management Association (OVRYCMA) was established and had 3 goals: (1) develop yellowfish as a catch-and-release-only fishery, (2) assist landowners and interested stakeholders with marketing yellowfish catch-and-release angling and general conservation issues, and (3) educate the public about OVRYCMA goals and increase support through a network of interested local and national citizens. Through fisher involvement, association volunteers recruited members among local landowners and developed a management strategy to conserve a heavily used and human-affected area containing important yellowfish habitat. To date, this project has successfully managed over $700 \mathrm{~km}$ of river frontage. The yellowfish fisheries are now valued at R1.2 billion (US $\$ 160$ million; estimated to be higher than the alien species fisheries; de Villiers 2007). Despite ongoing funding challenges, yellowfish fisheries are now receiving considerable conservation assistance. Furthermore, no hatchery-reared yellowfish have been stocked since 2000 and no invasive alien species may be legally stocked in associated rivers.

The diversity of stakeholders and early involvement of the association in guiding the process were critical to the association's success. The OVRYCMA demonstrated that natural resource conservation is possible without full government support, but that innovative techniques, a focused and committed management team, and agency support of management concepts are critical for success. The OVRYCMA experience also shows that fundraising efforts are essential to assure project implementation beyond the "concept" stage. Finally, conservation and management networks with links to the press, interested organizations, and the public can play a valuable role in project success by "marketing" their strategy to stakeholders. A measure of the initiative's success is that catchand-release angling is now being applied to both freshwater and marine indigenous South African species.

\section{Westslope Cutthroat Trout in Montana, United States}

In the western United States, Montana's Rocky Mountain Front is a well-known center of biological diversity; however, as of 2002, genetically pure westslope cutthroat trout (Oncorbynchus clarkii lewisi) occupied only between 13 and 35\% of their historic range (Shepard et al.
2003) and are increasingly hybridizing with introduced rainbow trout (O. mykiss) as they disperse to higher elevations (Hitt et al. 2003). New road development reduces habitat quality and increases the likelihood of non-native trout introduction and subsequent hybridization (Lee et al. 1997). Conservation of the remaining westslope cutthroat trout populations requires protection of the few remaining large blocks of undeveloped habitat.

In response to renewed oil and gas leasing, the Coalition to Protect the Rocky Mountain Front was formed to protect wildlands by preventing energy development in sensitive roadless areas. The coalition includes individual fishers, hunters, ranchers, national and regional nonprofit organizations, and the interested public, and benefits greatly from its strong partnership between traditional environmentalists and fishing and hunting interests. This diverse stakeholder group found common ground in their concern for maintaining wild areas. Through media coverage and grassroots lobbying efforts, the coalition has encouraged hunters and fishers to focus attention on the impacts of energy development on recreational opportunities and to provide their first-hand knowledge of resources at risk.

Media attention and articles published in popular fishing and hunting magazines proved central to the coalition's success, and grassroots concerns for fisheries and wildlife along the Front increased as awareness of threatened recreational resources grew among local hunters and fishers (Connelly 2004; Stalling 2005). Due in part to coalition pressure, legislation was passed in 2006 that permanently withdrew public lands along the Rocky Mountain Front from new energy leases and allowed for the retiring of existing leases. Soon after, the coalition retired another lease through purchase of exploration rights on almost 10,000 ha of roadless area from an energy firm.

Another factor in the coalition's success has been its focus on specific areas with high recreational, natural beauty, and wildlife values. In addition to the Rocky Mountain Front, similar coalitions of fishers, hunters, ranchers, and environmentalists have focused attention on energy development as a threat to public land that contains high-quality fishery habitats in Colorado's Roan Plateau, New Mexico's Valle Vidal, and the Wyoming Range. Such broad-based coalitions have gained significant political power (Kohler 2006), which demonstrates an additional value of coalitions: support for conservation-focused action in higher-level decisionmaking processes.

\section{Rockfish in British Columbia, Canada}

From the early 1990s Canadian recreational fishers complained to Canada's Department of Fisheries and Oceans (DFO) about an apparent decline in rockfish abundance in the Strait of Georgia ( 5 species of the genus Sebastes locally called yelloweye [S. ruberrimus], quillback [ $S$. 
maliger], copper [S. caurinus], china [S. nebulosus], and tiger [S. nigrocinctus]). These fishers were concerned about the rapidly growing commercial fishery targeting live capture of these species. These animals reside in easily identifiable reef habitat, which makes them particularly susceptible to harvest by recreational charter boats, and there was evidence that the recreational harvest had come to equal commercial extraction (Kronlund et al. 1999).

In 2000 recreational fishers began planning practical ways to meet DFO's 4 new management goals for inshore rockfish: (1) reduce total harvest, (2) establish no-take areas for their protection, (3) improve catch monitoring, and (4) establish a stock assessment framework. Two of these goals required detailed input from the recreational sector-appropriate measures to effect a harvest rate reduction of $75 \%$ and determine locations for a network of no-take reserves. The recreational community was represented by the Sport Fishing Advisory Board (SFAB), which was established by DFO in the 1960 s with a mandate to provide conservation and management advice to the federal fisheries minister on behalf of 400,000 licensed recreational fishers.

Catch and release was unacceptable in this case because DFO maintained that inshore rockfish rarely survive the barotrauma suffered during capture (DFO Canada 2002). The SFAB representatives instead proposed closed periods and areas and a reduction in daily bag limit from 5 to 1 (SFAB/DFO Canada 2002). During consultation with local SFAB committees, a network of 164 rockfish conservation areas (refugia) was identified that accounted for approximately $30 \%$ of the identified rockfish habitat in the overfished Strait of Georgia.

By 2005, 4 years after implementation of these new measures, the bag limit reduction combined with a closure of the lingcod fishery (which overlaps with rockfish habitat) resulted in an $81 \%$ decrease in the preimplementation recreational harvest of rockfish. When the lingcod fishery reopened, the recreational rockfish harvest increased slightly, prompting the SFAB to propose a further 2-week reduction in the next year's lingcod season. This change achieved the desired effect of keeping rockfish mortality within the desired limit.

This case demonstrates the contribution that an effective and inclusive consultation process can make to recreational fisheries management. Giving recreational stakeholders direct responsibility for helping solve management problems not only required them to become much more knowledgeable about the species and their habitat, but it was also good for the fishery and the fish.

\section{Rezoning of the Great Barrier Reef Marine Park, Australia}

The Great Barrier Reef Marine Park (GBRMP), created in 1975 and a World Heritage Site since 1981, is a large, multiple-use marine park of approximately $345,000 \mathrm{~km}^{2}$ (Fernandes et al. 2005). The GBRMP is facing increasing pressure from impacts related to user numbers (e.g., fishing effort, vessel traffic, habitat damage, pollution) and climate change (Moscardo \& Green 1999; Fernandes et al. 2005). A primary management tool that affects recreational fishing in the GBRMP is a graduated zoning system in which levels of marine-resources protection vary in different areas of the park and are implemented through restrictions or prohibitions of different activities.

In 1998 in response to the recognized inadequacy of existing protection in the GBRMP, the GBRMP Authority initiated the Representative Areas Program (RAP) as the basis for rezoning the GBRMP (Day et al. 2002). This program aimed to enhance regional biodiversity protection by developing a network of representative no-take areas. Scientific data and recreational fishers' data were used as input to the zoning plan (Cameron et al. 2007). During formal consultations, the GBRMPA received and analyzed nearly 32,000 submissions, approximately $45 \%$ of which were from people who identified themselves as recreational fishers (DEH 2006).

In 2004 implementation of the Great Barrier Reef Marine Park Zoning Plan 2003 increased the no-take areas within the GBRMP from approximately $4.5 \%$ to approximately 33\% (Fernandes et al. 2005). Information from consultations with recreational fishers was used to determine boundaries of no-take areas, conservation park zones that prohibit larger-scale fishing activities, and the provisions and definitions applied to fishing gears used in different zones.

Despite extensive involvement in the rezoning process, many recreational fishers expressed considerable dissatisfaction with the rezoning process (DEH 2006), although this sentiment was not universal. Some recreational fishing communities were satisfied with their inclusion in the process and have subsequently increased their involvement in GBRMP conservation and management activities. An example is the establishment of CapReef, a community-based monitoring program designed to improve community involvement in management of the GBRMP (CapReef 2005).

Face-to-face consultation with recreational fishers early in the rezoning process and throughout all phases assisted in their understanding of relevant issues, effective input, and subsequent support of the process. Community information sessions provided an informative, nonthreatening, and inclusive environment (Thompson et al. 2004). The use of geographic information systems to communicate place-based information was essential during rezoning (Lewis et al. 2003), and zoning maps with boundary coordinates and updated electronic charts increased fisher support and compliance with the new notake areas.

Despite exhaustive efforts by the GBRMP Authority in communication and consultation, the credibility of 
well-documented, GBRMP-specific, scientific information supporting an increased network of no-take areas was often questioned by fishers (Jago et al. 2007). There was a general sense of dissatisfaction with loss of fisheries access; thus, convincing recreational fishers that their views were incorporated in outcomes that do not reflect all of their preferred alternatives has been an ongoing challenge.

\section{Discussion}

Our case studies highlight key types of recreational fisher engagement in management, including monitoring, research, enforcement, conservation, management design (types and location), and advocacy and education (Table 1). These key activities developed out of specific needs in each situation and offer guidance on how recreational fishers can become involved in future projects. One unifying characteristic across these case studies is that recreational fishers may offer significant resources including, but not limited to, knowledge of spatial patterns of resource use and availability (Canada, Australia, Germany, Mongolia) direct involvement in restoration projects (South Africa, Germany); political leverage (United States); and grassroots support for research and conservation measures (Mongolia, Germany).

The key activities (Table 1) are predicted to vary in effectiveness with each case (Fig. 1). Through synthesis of these case studies, we identified 3 primary factors that affected the appropriate type and likelihood of involvement: (1) stakeholder degree of stewardship (low to high), (2) scale of the resource, user group, or management structure (small to large), and (3) source of impact(s) on the fishery (internal, external, or a combination) (Fig. 1).

Stakeholder environmental stewardship is an important factor because it facilitates support of management and conservation measures and a high level of commitment. High stewardship among fishers also fosters trust among stakeholder groups and between stakeholders and researchers. When fishers have a high degree of stewardship, through personal experiences or effective educational programs, they are more likely to become actively engaged in conservation (e.g., advocacy in Montana, conservation in Mongolia, enforcement in Germany; Fig. 1).

In our case studies the scale of the fishery, including size of the resource, user group, and management area, was often inversely related to the probability of fisher engagement. If the resource is small, fishers are more likely to feel responsible for its conservation (Arlinghaus 2006) and may perceive that there is a great probability that their actions will affect change (i.e., high level of behavioral control; Ajzen 1991). Thus involvement is more likely and may be effective in multiple types of activities (Table 1). A particular challenge in large-scale management is that cooperation between decision makers, agencies, nongovernmental organizations and fishers can be difficult, expensive, time consuming, and depend on government input. Additional considerations related to the scale factor include fishers' capacity in terms of leadership, resources, and level of organization; agency role and resources to complement or supplement fishers' resources; and other stakeholder groups that may act in concert with anglers' organizations.

The type and probability of recreational fisher involvement in conservation is also related to the nature of the threat to the fishery. When fishers are protecting a valued resource from threats external to recreational fishing, such as commercial fishing, habitat destruction, or invasive species, fisher involvement is likely to be high. Nevertheless, where threats are diffuse or otherwise directly attributable in whole or part to recreational fishing, there may be greater resistance by fishers to direct conservation involvement.

When the combination of factors leads to a high likelihood of fisher involvement (Fig. 1, top of triangle), increased opportunity exists to involve recreational fishers in multiple types of engagement (e.g., enforcement, advocacy, conservation, and research; Table 1 ). The case studies highlight the net benefit to conservation realized when such involvement occurs. For example, collaboration between scientists and recreational fishers can provide valuable and otherwise unobtainable (in a cost-effective manner) data on poorly studied species. Research-oriented programs are also likely to be more successful if local fisher knowledge, site-specific traditions, and key stakeholders and networks are incorporated. Partnerships can be more self-sustaining if recreational fishers provide funds and contribute to follow-up monitoring. Such partnerships are, in the long term, effective at increasing local capacity and fundraising, generating data, and providing education and incentives for local people to protect natural resources. Monitoring and enforcement of closed areas is typically poorly funded and is thus an area in which fisher cooperation can mean the difference between success and failure. The case studies in South Africa, Montana, and British Columbia demonstrate instances in which conservation would likely not have happened at all were it not for the initiative of recreational fishers. The cases presented thus highlight the net positive benefit to conservation of recreational fisher involvement.

Despite the highly decentralized and heterogeneous nature of the world's recreational fishery sector (Sutinen \& Johnston 2003), our case studies highlight that fishers' active involvement in conservation can occur at multiple levels under private and public fishing rights regimes. Recreational fishers in open-access fisheries have historically contributed indirectly to aquatic conservation via permit and license sales and self-monitoring of their 
Table 1. Synthesis of successful recreational fisher engagement in management and conservation.

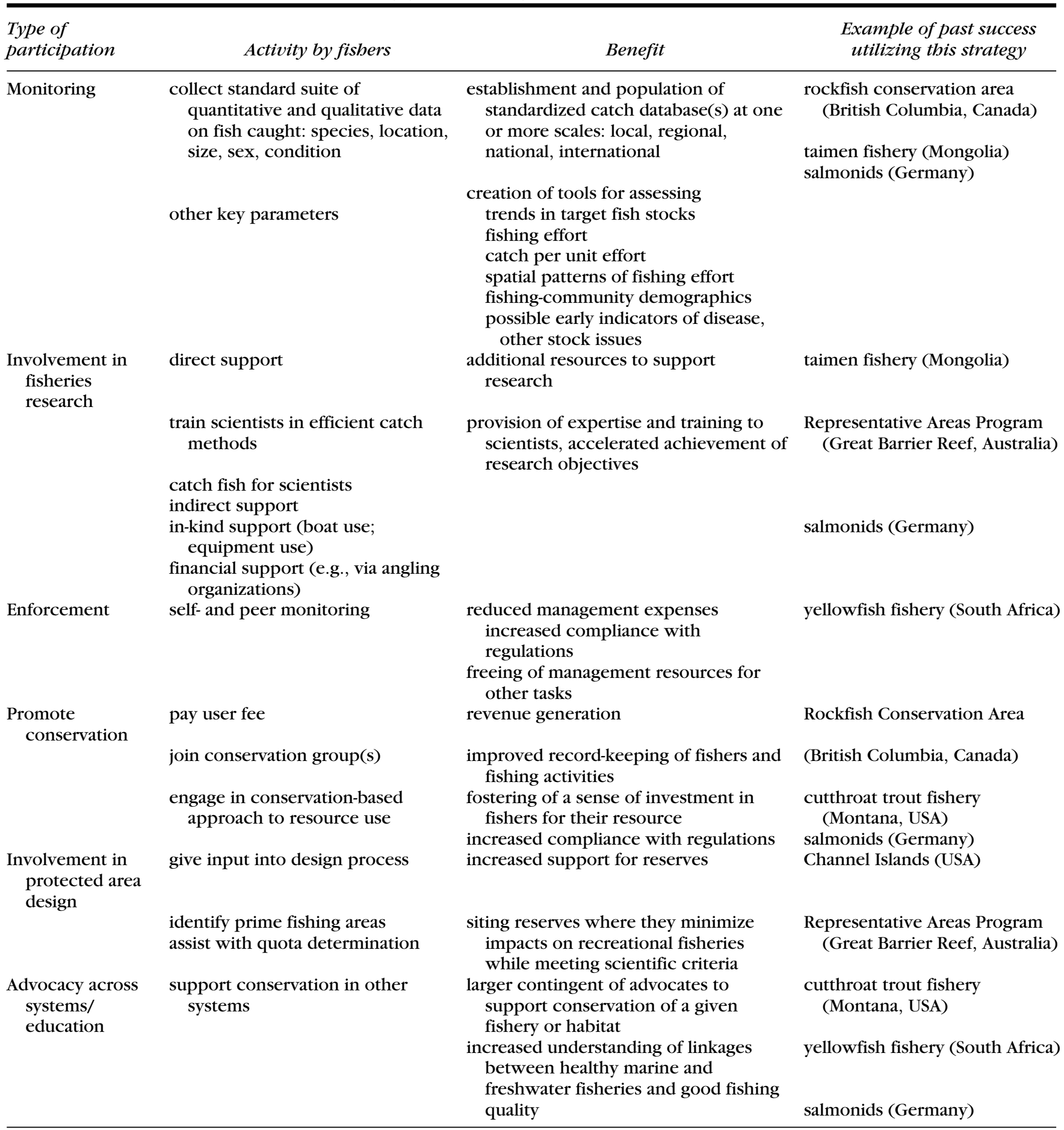

"favorite fishing holes," but our case studies demonstrate opportunities for more direct involvement. Closed-access fisheries, with legal requirements to manage and conserve that accompany purchase of fishing rights, have a distinct history of fishers' management and resource conservation inter alia due to an intrinsic self-interest and direct benefits from enhanced fish stocks (e.g., Bate
2001; Arlinghaus 2006). Nevertheless, even in a private fishing-rights regime, major challenges for sustainable recreational fisheries management exist, including fishers' lack of awareness when they contribute to stock declines and the negative impacts of stocking (Arlinghaus 2006). Prime opportunities to involve fishers in conservation may occur in programs and organizations that 
represent recreational fishing. Within functioning angler and community organizations, ample opportunities exist to work directly with managers, scientists, and other stakeholders to provide additional resources to support scientific data collection, project implementation, and monitoring (CapReef 2005). This can, in the long term, reduce stressors on aquatic systems, which can enhance socioeconomic benefits of recreational fisheries and foster dedicated recreational fisher involvement in conservation and management.

We contend, on the basis of the global case studies presented here, that recreational fishers can facilitate successful conservation projects to counterbalance the potential downsides associated with recreational fishing (e.g., Post et al. 2002; Coleman et al. 2004). Our framework (Fig. 1) provides a roadmap for improved fisher participation in conservation and management of economically and socially valuable fishery resources and a guide for involving recreational fishers in other conservation projects.

\section{Literature Cited}

Ajzen, I. 1991. The theory of planned behavior. Organizational Behavior and Human Decision Processes 50:179-211.

Arlinghaus, R. 2006. Overcoming human obstacles to conservation of recreational fishery resources, with emphasis on Europe. Environmental Conservation 33:46-59.

Arlinghaus, R., and S. J. Cooke. 2008. Recreational fisheries: socioeconomic importance, conservation issues and management challenges. In press in B. Adams, editor. Recreational hunting, conservation and rural livelihoods: science and practice. Blackwell Science, Oxford, United Kingdom.

Arlinghaus, R., T. Mehner, and I. G. Cowx. 2002. Reconciling traditional inland fisheries management and sustainability in industrialized countries, with emphasis on Europe. Fish and Fisheries 3:261316.

Bate, R. 2001. Saving our streams: the role of the Anglers' conservation association in protecting English and Welsh Rivers. The Institute of Economic Affairs and Profile Books, London.

Brämick, U., U. Rothe, H. Schuhr, M. Tautenhahn, U. Thiel, C. Wolter, and S. Zahn. 1999. Fische in Brandenburg: Verbreitung und Beschreibung der märkischen Fischfauna. Ministerium für Ernährung, Landwirtschaft und Forsten des Landes Brandenburg and Institut für Binnenfischerei e.V. Potsdam-Sacrow, Groß Glienicke. Mercedes Druck, Berlin.

Cambray, J. A. 2003. Impact on indigenous species biodiversity caused by the globalization of alien recreational freshwater fisheries. Hydrobiologia 500:217-230.

Cameron, D. S., et al. 2007. Use of fisheries data in rezoning the great barrier reef marine park. 2007. Pages 445-446 in J. C. Day, J. Senior, S. Monk, and N. Neal, editors. First international marine protected areas congress conference proceedings. Available from http://www.impacongress.org (accessed July 2007).

CapReef. 2005. Information on a community monitoring program in the GBRMP. InfoFish, Queensland, Australia. Available from http://www.info-fish.net/browseResults.asp? page $=1 \&$ mode $=$ viewdetail\&name $=$ CapReef $($ accessed January 2007).

Coleman, F. C., W. F. Figueira, J. S. Ueland, and L. B. Crowder. 2004. The impact of United States recreational fisheries on marine fish populations. Science 305:1958-1960.
Connelly, J. 2004. Frontal assault. National Wildlife Magazine 42:25-30.

Cooke, S. J., and I. G. Cowx. 2004. The role of recreational fishing in global fish crises. BioScience 54:857-859.

Cooke, S. J., and I. G. Cowx. 2006. Contrasting recreational and commercial fishing: searching for common issues to promote unified conservation of fisheries resources and aquatic environments. Biological Conservation 128:93-108.

Day, J., et al. 2002. The Representative Areas Program for protecting biodiversity in the Great Barrier Reef World Heritage Area. Pages 687696 in M. K. Moosa, editor. Proceedings of the ninth international coral reef symposium 2000. Ministry of Environment, Indonesian Institute of Sciences, International Society for Reef Studies, Jakarta, Indonesia.

Dayton, P. K., S. F. Thrush, M. T. Agardy, and R. J. Hofman. 1995. Environmental effects of marine fishing. Aquatic Conservation: Marine and Freshwater Ecosystems 5:205-232.

DEH (Department of Environment and Heritage). 2006. Review of the Great Barrier Reef Marine Park Act 1975. Review panel report. Department of the Environment and Water Resources, Canberra, Australia. Available from http://www.environment.gov.au/coasts/ publications/gbr-marine-park-act.html (accessed March 2007).

de Villiers, P. 2007. The state of yellowfishes in South Africa 2007. Pages 7-14 in L. Wolhuter and D. Impson, editors. Report for the Water Research Commission by the Yellowfish Working Group. WRC Report TT 302/07. Water Research Commission, Pretoria.

DFO (Department of Fisheries and Oceans) Canada. 2002. Backgrounder BG-PR-02-007E. DFO Canada, Ottawa, Ontario. Available from http://www-comm.pac.dfo-mpo.gc.ca/pages/release/ bckgrnd/2002/bg007_e.htm (accessed March 2007)

Eby, L. A., W. J. Roach, L. B. Crowder, and J. A. Stanford. 2006. Effects of stocking-up freshwater food webs. Trends in Ecology \& Evolution 21:576-584.

FAO (Food and Agriculture Organization). 2006. The state of the world fisheries and aquaculture 2006. FAO Fisheries Department, Rome.

Fernandes, L., et al. 2005. Establishing representative no-take areas in the Great Barrier Reef: large scale implementation of theory on marine protected areas. Conservation Biology 19:1733-1744.

Harrison, I. J., and M. L. J. Stiassny. 1999. The quiet crisis: a preliminary listing of the freshwater fishes of the world that are extinct or 'missing in action.' Pages 271-331 in R. D. E. MacPhee, editor. Extinctions in neartime: causes, contexts, and consequences. Plenum Press, New York.

Hitt, N. P., C. A. Frissell, C. C. Muhlfeld, and F. W. Allendorf. 2003. Spread of hybridization between native westslope cutthroat trout, Oncorbynchus clarki lewisi, and nonnative rainbow trout, Oncorhynchus mykiss. Canadian Journal of Fisheries and Aquatic Sciences 60:1440-1451.

Hogan, Z., D. Gilroy, J. Vander Zanden, S. Chandra, B. Allen, and M. Erdenebat. 2006. Taimen conservation project: interim Science Team report. Taimen Conservation Fund, Ulaanbaatar, Mongolia.

Jago, B., et al. 2007. Involving the community early-the variable role that communities can play in MPA management: experiences and lessons learned on the Great Barrier Reef. Pages 353-355 in J. C. Day, J. Senior, S. Monk, and N. Neal, editors. First international marine protected areas congress conference proceedings. Available from http://www.impacongress.org (accessed July 2007)

Jennings, S., and Kaiser, M. J. 1998. The effects of fishing on marine ecosystems. Advances in Marine Biology 34:201-352.

Kohler, J. 2006. Outdoors fans unite on development. Associated Press, Rifle, Colorado.

Kronlund, A. R., K. L. Yamanaka, and G. D. Workman. 1999. Inshore rockfish stock assessment for the west coast of Canada in 1998 and recommendations for 1999/2000. Research Document 99/58. Canadian Stock Assessment Secretariat, Ottawa, Canada.

Lee, D. C., J. R. Sedell, B. E. Rieman, R. F. Thurow, and J. E. Williams. 1997. Broadscale assessment of aquatic species and habitats. Pages 1058-1496 in T. M. Quigley et al., editors. An assessment of 
ecosystem components in the interior Columbia Basin and portions of the Klamath and Great Basins. PNW-GTR-405. U.S. Department of Agriculture Forest Service, Portland, Oregon.

Lewin, W.-C., R. Arlinghaus, and T. Mehner. 2006. Documented and potential biological impacts of recreational fishing: insights for management and conservation. Reviews in Fisheries Science 14:305367.

Lewis, A., S. Slegers, D. Low, L. Muller, L. Fernandez, and J. Day. 2003. Use of spatial analysis and GIS techniques to rezone the Great Barrier Reef Marine Park. Coastal GIS workshop. University of Wollongong, Australia.

Moscardo, G., and D. Green. 1999. Age and activity participation on the Great Barrier Reef. Tourism Recreation Research 24:5768.

Myers, R. A., and B. Worm. 2003. Rapid worldwide depletion of predatory fish communities. Nature 423:280-283.

Pauly, D., A. Christensen, J. Dalsgaard, R. Froese, and F. J. Torres. 1998. Fishing down marine food webs. Science 279:860-863.

Pereira, D. L., and M. J. Hansen. 2003. A perspective on challenges to recreational fisheries management: summary of the symposium on active management of recreational fisheries. North American Journal of Fisheries Management 23:1276-1282.

Post, J. R., M. Sullivan, S. Cox, N. P. Lester, C. J. Walters, E. A. Parkinson, A. J. Paul, L. Jackson, and B. J. Shuter. 2002. Canada's recreational fisheries: the invisible collapse? Fisheries 27:6-17.

Radomski, P. J. 2003. Initial attempts to actively manage recreational fishery harvest in Minnesota. North American Journal of Fisheries Management 23:1329-1342.
SFAB/DFO (Sport Fisheries Advisory Board/Department of Fisheries and Oceans) Canada. 2002. South coast rockfish consultation meeting. Fisheries and Oceans, Canada. Available from http://wwwcomm.pac.dfo-mpo.gc.ca/pages/consultations/fisheriesmgmt/ rockfish/rockfish032002mr_e.pdf (accessed March 2007).

Shepard, B. B., B. E. May, and W. Urie. 2003. Status of westslope cutthroat trout (Oncorbynchus clarki lewisi) in the United States: 2002. Westslope Cutthroat Trout Interagency Conservation Team, Montana Fish, Wildlife and Parks, Bozeman, Montana.

Stalling, D. 2005. Angling for the Front. Big Sky Journal 12:134-141.

Sullivan, M. G. 2003. Active management of walleye fisheries in Alberta: dilemmas of managing recovering fisheries. North American Journal of Fisheries Management 23:1343-1358.

Sutinen, J. G., and R. J. Johnston. 2003. Angling management organizations: integrating the recreational sector into fishery management. Marine Policy 27:471-487.

Thompson, L., B. Jago, L. Fernandes, and J. Day. 2004. Barriers to communication-how these critical aspects were addressed during public participation for the rezoning of the Great Barrier Reef Marine Park. Department of the Environment and Water Resources, Canberra, Australia. Available from http://gbrmpa.gov.au/_data/ assets/pdf_fil/0016/8251/Breaking_through_the_barriers_15April 0420FINAL.pdf (accessed March 2007).

Woodford, D. J., N. D. Impson, J. A. Impson, and I. R. Bills. 2005. The predatory impact of invasive alien smallmouth bass, Micropterus dolomieu (Teleostei: Centrachidae), on indigenous fish in a Cape Floristic Region mountain stream. African Journal of Aquatic Sciences 30:167-174.

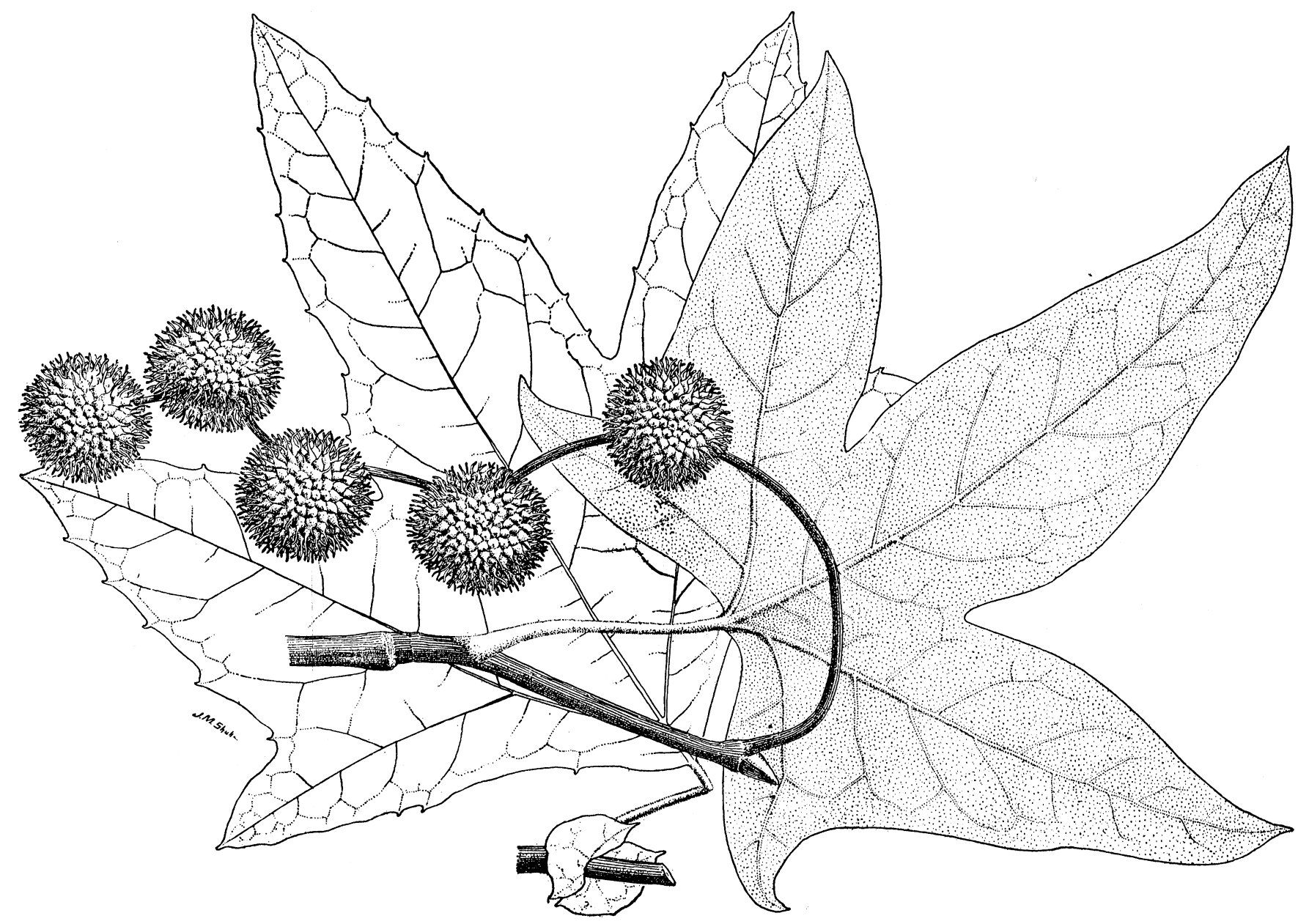

